\title{
Direct-Fed Microbial Supplementation on the Performance of Dairy Cattle During the Transition Period ${ }^{1}$
}

\author{
J. E. Nocek, ${ }^{*}$ W. P. Kautz,† J. A. Z. Leedle,† and E. Block $\ddagger^{, 2}$ \\ *Spruce Haven Farm and Research Center, Union Springs, NY 13160 \\ †Chr. Hansen's Biosystems, Milwaukee, WI 53214-4298 \\ $\ddagger$ McGill University, Ste. Anne De Bellevue, Quebec, Canada
}

\section{ABSTRACT}

The influence of a direct-fed microbial (DFM) on the prepartum period and the effects on production performance during the postpartum period was investigated using 64 multiparous Holstein cows. Two close-up dry cow diets were fed to two groups of 32 cows each starting $21 \mathrm{~d}$ precalving as follows: 1) no DFM and 2) DFM. Postcalving cows were fed a lactation ration with or without DFM supplementation. Direct-fed microbial supplementation contained approximately $5 \times 10^{9} \mathrm{cfu}$ of yeast and $5 \times 10^{9}$ cfu of bacteria (Enterococcus faecium, two strains) topdressed in a 90 -g supplement/cow per day in both preand postpartum periods. The DMI during the prepartum period was not affected by DFM supplementation. During the postpartum period, DMI, milk yield, and milk protein content were higher for cows receiving DFM supplementation compared with no DFM. Blood glucose and insulin levels were higher and NEFA levels were lower for cows receiving DFM during the postpartum period. These data suggest that targeted DFM supplementation increased DMI and milk production postpartum. Blood metabolite information would suggest this response was associated with more glucose being made available and less fatty acids being mobilized from lipid stores.

(Key words: direct-fed microbial, production)

Abbreviation key: DFM = direct-fed microbials.

\section{INTRODUCTION}

Recently, Nocek et al. (2002a) reported that feeding a combination of Lactobacillus plantarum and Enterococcus faecium significantly increased the nadir within the diurnal cycle of ruminal $\mathrm{pH}$ when these microbes were

\footnotetext{
Received April 19, 2002.

Accepted September 9, 2002.

Corresponding author: J. E. Nocek; e-mail: jimnocek@worldnet. att.net.

${ }^{1}$ Reprint requests to W. P. Kautz, Chr. Hansen's Biosystems, Milwaukee, WI 53214-4298.

${ }^{2}$ Currently with Church and Dwight Co., Piscataway, NJ 085435927.
}

supplemented daily into the rumen. The rationale for this response was that the supplemented direct-fed microbial (DFM) were providing a constant level of lactic acid to the rumen microbiota. This tonic production of lactate was hypothesized to allow the fastidious lactate-utilizing microbes to sustain a metabolically active population. The result would be to enable the lactate utilizers to sequester more lactate at specific times when lactic acid concentrations undulate as a result of diurnal feeding behavior. In this report (Nocek et al., 2002a), there was evidence to show that DFM supplementation increased the rate of DM digestibility of specific ingredients, presumably associated with increased $\mathrm{pH}$. These ruminal benefits could have a positive influence on postpartum performance (Nocek 1997; Owens et al., 1998). In a crosssectional field study, Garrett et al. (1997) suggested that subacute ruminal acidosis may be present in high producing herds and that prepartum diet NFC level may be an important determinant of early lactation ruminal $\mathrm{pH}$. The objective of this study was to evaluate the effect of DFM supplementation during the pre- and postpartum period on transition performance of dairy cattle.

\section{MATERIALS AND METHODS}

Sixty-four multiparous Holstein cows were blocked by previous lactation milk into four treatment groups and used in this study from $3 \mathrm{wk}$ prepartum through $10 \mathrm{wk}$ postpartum. The treatment groups consisted of two prepartum transition diets (with and without DFM) offered to two groups of 32 cows each beginning at $21 \mathrm{~d}$ prepartum. After calving, 16 cows from each prepartum group were individually fed a lactation diet either with or without DFM supplementation.

The ingredient and nutrient composition of the prepartum diets is shown in Table 1 and the lactation diets in Table 2. The DFM consisted of a yeast (Saccharomyces cervisiae: Biomate, yeast plus, Chr. Hansen, Milwaukee, WI), and two Enterococcus strains were selected for their ability to provide the desired lactic acid concentration under ruminal conditions. The DFM was offered at $90 \mathrm{~g} /$ cow per day incorporated into a portion $(250 \mathrm{~g})$ of supplement that was part of the formulated TMR and top- 
Table 1. Ration composition for diets offered $21 \mathrm{~d}$ prepartum through parturition. ${ }^{1}$

\begin{tabular}{lc}
\hline Ingredient & \%DM basis \\
\hline Mixed haylage & 30.0 \\
Corn silage & 30.0 \\
Corn, ground & 9.1 \\
Supplement & 30.0 \\
Limestone & 0.9 \\
Nutrient & \\
CP, \% & 16.0 \\
DIP, \% of CP & 68.0 \\
NDF, \% & 35.6 \\
Ca, \% & 1.25 \\
P,\% & 0.48 \\
$\mathrm{Mg}, \%$ & 0.34 \\
\hline
\end{tabular}

${ }^{1}$ Offered either with or without $90 \mathrm{~g}$ of direct-fed microbials (Enterococcus faecium) top-dressed per day.

${ }^{2}$ Purina commercial transition cow supplement containing $30 \% \mathrm{CP}$ or which $50 \%$ is undegradable. vitamins, minerals, corn and cornstarch, and wheat and wheat starch $\left(1.9 \mathrm{Mcal} / \mathrm{kg} \mathrm{NE} \mathrm{N}_{\mathrm{L}}\right)$.

${ }^{3} \mathrm{DIP}=$ degradable intake protein

dressed to ensure all $90 \mathrm{~g}$ were consumed. The $90 \mathrm{~g}$ of DFM contained $5 \times 10^{9} \mathrm{cfu}$ of yeast and $5 \times 10^{9} \mathrm{cfu}$ of bacteria.

Pre- and postpartum diets were offered as a TMR and fed twice daily ad libitum to assure at least $10 \%$ refusal, except for the $250 \mathrm{~g}$ (supplement or supplement + DFM). Weighbacks were recorded before the morning feeding and discarded. Daily DMI per cow were recorded for the entire trial period. In addition, daily milk production and weekly composition were measured during the postpartum period. All forages and diets were sampled weekly and composited monthly, stored frozen, and analyzed for CP (AOAC, 1990), NDF (Van Soest et al. 1991), Ca, P, and $\mathrm{Mg}$ (AOAC, 1990).

Blood samples were taken daily from $21 \mathrm{~d}$ to parturition, and continued daily from parturition to $21 \mathrm{~d}$ postpartum then weekly from d 22 until the end of the study. Blood samples were taken before the morning feeding, because this should reflect the time of highest NEFA and BHBA during any 24-h period. Rumen fluid samples were obtained via stomach tube $3 \mathrm{~h}$ postfeeding on d 14, 10, and 5 through $d 1$ prepartum. NEFA and glucose concentrations were determined by colorimetric assay with commercial kits (WAKO Chemicals, Dallas, TX and kit \#510, Sigma Chemical Co., St. Louis, MO, respectively). Plasma BHBA was determined by the method of Gibbard and Watkins, (1968). Insulin was determined by radioimmunoassay (Coat-a-Count Insulin, Diagnostic Products Corporation, Los Angeles, CA).

The number of animals that completed the trial for each group were $12,14,13$, and 15 for no DFM, DFM preand postpartum, DFM prepartum and DFM postpartum, respectively. Animals removed from the study were removed for the following reasons: five for calving complica-
Table 2. Composition lactating cow diet. ${ }^{1}$

\begin{tabular}{lc}
\hline Ingredient & \%DM basis \\
\hline Corn silage & 16.8 \\
Haylage & 28.6 \\
High-moisture ear corn & 8.5 \\
Ground shell corn $^{2}$ & 20.9 \\
Wheat starch $^{2}$ & 1.6 \\
Protein supplement $^{3}$ & 9.9 \\
Rumen inert fat $^{4}$ & 12.8 \\
Sodium bicarbonate & 1.00 \\
Vitamin-mineral premix & 1.9 \\
Limestone & 0.007 \\
Magnesium oxide & 0.003 \\
Nutrient & \\
CP, \% & 18.6 \\
UIP, \% of CP & 42.6 \\
NE, Mcal/kg & 1.86 \\
ADF, \% & 17.6 \\
NDF, \% & 29.5 \\
NFC, \% & 44.6 \\
Fat, \% & 4.1 \\
Ca, \% & 1.4 \\
P, \% & 0.5 \\
Mg, \% & 0.4 \\
\hline
\end{tabular}

${ }^{1}$ Offered either with or without $90 \mathrm{~g}$ of direct-fed microbials (Enterococcus faecium) top-dressed per day.

${ }^{2}$ Fermentable energy supplement (Purenergy) based on wheat starch containing $14.8 \% \mathrm{CP}$ and $1.99 \mathrm{Mcal} / \mathrm{kg}$ of $\mathrm{NE}_{\mathrm{L}}$. Agribrand Canada, Brossard, Quebec, Canada.

${ }^{3}$ Commercial protein supplement (Maxitech) containing $45.5 \% \mathrm{CP}$, $45 \%$ UIP, and $2.05 \mathrm{Mcal} / \mathrm{kg}$ of $\mathrm{NE}_{\mathrm{L}}$. Agribrand Canada, Brossard, Quebec, Canada.

${ }^{4}$ Inert fat-based supplement (Energia) containing 37\% CP, 60\% $\mathrm{UIP}$, and $3 \mathrm{Mcal} / \mathrm{kg}$ of $\mathrm{NE}_{\mathrm{L}}$. Agribrand Canada, Brossard, Quebec, Canada.

tions, three for recurrent milk fever, and one for a broken hip; there was also a severe clinical mastitis situation. There were insufficient numbers to statistically determine if any affect of DFM on normal postpartum production diseases were present. The number of clinical ketosis was approximately two cases/treatment.

Statistical analysis during the pre- and postpartum period parameters were evaluated by a split-plot-in-time for repeated measures procedure of SAS (1996) with the model as follows: dependent variable $=\mu+$ treatment + period + cow (treatment) + treatment $\times$ period $+\mathrm{E}$, where $\mu$ is the overall mean of the population and $\mathrm{E}$ is the random error. During the prepartum period, treatments were no DFM or DFM. During the postpartum period, treatments were no DFM, DFM pre- and postpartum, DFM prepartum only, DFM postpartum only. When treatment was significant $(P<0.05)$, Tukey-Kramer (Kramer, 1956) test was used to identify treatment effects within period.

\section{RESULTS}

Dry matter intake responses are reported for $\mathrm{d} 21$ through 8 prepartum and for the last $7 \mathrm{~d}$ prepartum 
Table 3. Dry matter intake, plasma concentration of BHBA and NEFA of cows prepartum supplemented with direct-fed microbial (DFM).

\begin{tabular}{|c|c|c|c|c|c|c|}
\hline \multirow[b]{3}{*}{ Parameter } & \multicolumn{6}{|c|}{ Days prepartum } \\
\hline & \multicolumn{3}{|c|}{21 through $8 \mathrm{~d}$} & \multicolumn{3}{|c|}{$7 \mathrm{~d}$} \\
\hline & No DFM & DFM & SEM & No DFM & DFM & SEM \\
\hline DMI, kg/d & $10.1^{\mathrm{a}}$ & $12.0^{\mathrm{a}}$ & 0.08 & $7.1^{\mathrm{b}}$ & $7.7^{\mathrm{b}}$ & 0.7 \\
\hline BHBA, $\mu \mathrm{M} / \mathrm{L}$ & $0.490^{\mathrm{b}}$ & $0.524^{\mathrm{b}}$ & 0.062 & $0.624^{\mathrm{a}}$ & $0.601^{\mathrm{a}}$ & 0.078 \\
\hline NEFA, $\mu \mathrm{M} / \mathrm{L}$ & $340^{\mathrm{b}}$ & $323^{\mathrm{b}}$ & 32 & $407^{\mathrm{a}}$ & $391^{\mathrm{a}}$ & 26 \\
\hline
\end{tabular}

${ }^{\mathrm{a}, \mathrm{b}}$ Effect of period values in the same row with different superscripts are different $(P<0.05)$.

(Table 3). There was no effect of DFM on DMI from d 21 through 8 prepartum. DMI was reduced $(P<0.05)$ in the last $7 \mathrm{~d}$ vs. the previous $14 \mathrm{~d}$ prior to expected calving.

Regardless of treatment, both NEFA and BHBA levels were higher $(P<0.05)$ for the last $7 \mathrm{~d}$ than for the previous $14 \mathrm{~d}$ before expected calving date (Table 3). Treatment with DFM had no effect on either blood parameter prepartum. DFM supplementation influenced ruminal $\mathrm{pH}$ (Table 4). From d 5 through d 1 prepartum, cows supplemented with DFM had higher ruminal $\mathrm{pH}$ values than did nonsupplemented cows. Furthermore, cows supplemented with DFM showed less of a decline in rumen $\mathrm{pH}$ when comparing the average of $\mathrm{d} 14$ and 10 prepartum to $\mathrm{d} 1$ prepartum. Although the stomach tube sampling procedure is somewhat questionable due to potential contamination with saliva, results did reflect treatment differences seen in another study with DFM (Nocek et al., 2002a). In addition, others (Nocek et al., 2002b) have shown ruminal $\mathrm{pH}$ to reduce from $21 \mathrm{~d}$ prepartum to calving.

The effect of DFM supplementation, postpartum data will be viewed as a treatment effect at various treatment scenarios pre- and postpartum, i.e., no DFM, DFM both pre- and postpartum, DFM prepartum only, and DFM postpartum only (Table 5). For DMI, from d 1 through 7, supplementing DFM pre- and postpartum resulted in more DMI consumed than either no DFM or DFM fed prepartum only. Cows fed DFM postpartum only were not different from other treatments. During wk 2 and 3 postpartum, cows fed DFM pre- and postpartum and postpartum only had higher intakes than those fed no DFM or fed only during the postpartum period. The same tendency $(P<0.10)$ was demonstrated from d 22 through 70. Milk production was higher for cows that received DFM both pre- and postpartum than no DFM but not different than other treatments during wk 1 postpartum. On d 8 through 21 , cows consuming DFM pre- and postpartum produced more milk than cows receiving no DFM or DFM prepartum only but not different from those receiving DFM postpartum only. This same general tendency $(P<0.10)$ was demonstrated from wk 3 through 10 postpartum. Although there were no significant effects of treatment on milk fat percentage, cows that received DFM regardless of stage tended to have numerically higher milk fat percentage than those that did not receive DFM. During the first week postpartum, milk protein percentage was high and similar among treatments. From wk 2 through 10, cows receiving DFM regardless of stage produced milk with a higher $(P<0.05)$ protein percentage than those that did not receive DFM with the exception of those receiving DFM prepartum only from wk 2 through 3 not being different from other treatments.

Supplementing with DFM prepartum only had no influence on blood glucose, insulin, BHBA, of NEFA compared with not receiving DFM (Table 6). DFM supplementation pre- and postpartum increased $(P<0.05)$ glucose and insulin concentration compared with no DFM or when supplemented prepartum only, but not different from those supplemented postpartum only. However, values were numerically higher for those fed DFM postpar-

Table 4. Ruminal $\mathrm{pH}^{1}$ with time prepartum for cows supplemented with or without a direct-fed microbial (DFM).

\begin{tabular}{llllll}
\hline & \multicolumn{5}{c}{ Days prepartum } \\
\cline { 2 - 6 } Treatment & 14 and $10 \mathrm{~d}^{2}$ & $5,4,3 \mathrm{~d}$ & $2 \mathrm{~d}$ & $1 \mathrm{~d}$ & SEM \\
\hline No DFM & $6.81^{\mathrm{d}}$ & $6.59^{\mathrm{e}}$ & $6.60^{\mathrm{e}}$ & $6.46^{\mathrm{c}}$ & 0.09 \\
DFM & $6.87^{\mathrm{d}}$ & $6.72^{\mathrm{d}}$ & $6.69^{\mathrm{d}}$ & $6.57^{\mathrm{b}}$ & 0.07 \\
\hline
\end{tabular}

${ }^{1}$ Rumen fluid samples were obtained via stomach tube.

${ }^{\mathrm{b}, \mathrm{c}}$ Means in the same column with different superscripts are significantly $(P<0.05)$ different.

d,e Means in the same column with different superscripts are significantly $(P<0.10)$ different.

${ }^{2}$ Drop in $\mathrm{pH}$ for $\mathrm{d} 14$ and 10 vs. $\mathrm{d} 1$ prepartum was less $(P<0.05)$ for diets with DFM. 
Table 5. Dry matter intake and production parameters for cows supplemented with and without a directfed microbial (DFM) both pre- and postpartum and each separately.

\begin{tabular}{|c|c|c|c|c|c|}
\hline \multirow[b]{2}{*}{ Variable } & \multicolumn{5}{|c|}{ Treatment } \\
\hline & No DFM & $\begin{array}{l}\text { DFM pre- and } \\
\text { postpartum }\end{array}$ & $\begin{array}{l}\text { DFM } \\
\text { prepartum } \\
\text { only }\end{array}$ & $\begin{array}{l}\text { DFM } \\
\text { postpartum } \\
\text { only }\end{array}$ & SEM \\
\hline \multicolumn{6}{|l|}{ DMI, kg/d } \\
\hline $1-7 \mathrm{~d}$ & $12.9^{\mathrm{ab}}$ & $15.3^{\mathrm{a}}$ & $13.8^{\mathrm{b}}$ & $14.1^{\mathrm{ab}}$ & 1.1 \\
\hline $8-21 \mathrm{~d}$ & $18.4^{\mathrm{b}}$ & $21.2^{\mathrm{a}}$ & $19.1^{\mathrm{b}}$ & $20.4^{\mathrm{b}}$ & 1.3 \\
\hline $22-70 \mathrm{~d}$ & $24.6^{\mathrm{cd}}$ & $25.1^{\mathrm{c}}$ & $24.7^{\mathrm{d}}$ & $25.2^{\mathrm{c}}$ & 0.7 \\
\hline \multicolumn{6}{|l|}{ Milk, kg/d } \\
\hline $1-7 \mathrm{~d}$ & $22.1^{\mathrm{b}}$ & $24.4^{\mathrm{a}}$ & $23.1^{\mathrm{ab}}$ & $23.5^{\mathrm{ab}}$ & 0.9 \\
\hline $8-21 d$ & $34.5^{\mathrm{b}}$ & $36.1^{\mathrm{a}}$ & $35.1^{\mathrm{b}}$ & $35.5^{\mathrm{ab}}$ & 0.7 \\
\hline $22-70 \mathrm{~d}$ & $48.2^{\mathrm{d}}$ & $49.1^{\mathrm{c}}$ & $48.9^{\text {cd }}$ & $49.5^{\mathrm{c}}$ & 0.5 \\
\hline \multicolumn{6}{|c|}{ Milk fat, $\%$} \\
\hline $1-7 \mathrm{~d}$ & 4.23 & 4.63 & 4.53 & 4.58 & 0.04 \\
\hline $8-21 \mathrm{~d}$ & 3.41 & 3.53 & 3.51 & 3.5 & 0.05 \\
\hline $22-70$ & 3.36 & 3.47 & 3.42 & 3.39 & 0.05 \\
\hline \multicolumn{6}{|c|}{ Milk protein, \% } \\
\hline $1-7 \mathrm{~d}$ & 3.98 & 4.01 & 4.0 & 3.99 & 0.01 \\
\hline $8-22 \mathrm{~d}$ & $3.21^{b}$ & $3.35^{\mathrm{a}}$ & $3.3^{\mathrm{ab}}$ & $3.36^{\mathrm{a}}$ & 0.07 \\
\hline $22-70 \mathrm{~d}$ & $3.01^{b}$ & $3.27^{\mathrm{a}}$ & $3.19^{\mathrm{a}}$ & $3.2^{\mathrm{a}}$ & 0.11 \\
\hline
\end{tabular}

${ }^{\mathrm{ab}}$ Means in the same row with different superscripts differ $(P<0.05)$.

${ }^{\mathrm{c}, \mathrm{d}}$ Means in the same row with different superscripts differ $(P<0.10)$.

tum compared with those that received no DFM or those that received DFM only during the prepartum period. During the first $3 \mathrm{wk}$ postpartum, there was no treatment effect on blood BHBA or NEFA. After $22 \mathrm{~d}$ postpartum, feeding DFM pre- and postpartum reduced $(P<0.05)$ BHBA and NEFA compared with no supplementation or only prepartum (Table 6 ).

\section{DISCUSSION}

When evaluating blood parameters in terms of ease of transition (less predisposition to metabolic disease) and animal performance for this study, the optimal situation would be to have any particular treatment elevate blood glucose and insulin with a reduction in BHBA and NEFA compared with other treatments or the nontreated control. This scenario suggests a reduction of fatty acid mobilization, more complete oxidation of fatty acids and increased energy derived from dietary carbohydrate sources (i.e., DMI) to meet postpartum energy needs. Drackley (1999) indicated the source of metabolic fuels that constitutes metabolizable energy may be critical for fine-tuning events that trigger either clinical or subclini-

Table 6. Blood parameters for cows supplemented with and without a direct-fed microbial (DFM) for both pre- and postpartum and each separately.

\begin{tabular}{|c|c|c|c|c|c|}
\hline \multirow[b]{2}{*}{ Variable } & \multicolumn{5}{|c|}{ Treatment } \\
\hline & No DFM & $\begin{array}{l}\text { DFM pre- and } \\
\text { postpartum }\end{array}$ & $\begin{array}{l}\text { DFM } \\
\text { prepartum } \\
\text { only }\end{array}$ & $\begin{array}{l}\text { DFM } \\
\text { postpartum } \\
\text { only }\end{array}$ & SEM \\
\hline \multicolumn{6}{|l|}{ Glucose } \\
\hline $1-7 \mathrm{~d}$ & $51.1^{\mathrm{a}}$ & $59.3^{\mathrm{b}}$ & $50.7^{\mathrm{a}}$ & $55.9^{\mathrm{ab}}$ & 4.1 \\
\hline $8-21 \mathrm{~d}$ & $49.7^{\mathrm{a}}$ & $55.7^{\mathrm{b}}$ & $51.8^{\mathrm{ab}}$ & $53.6^{\mathrm{ab}}$ & 2.6 \\
\hline $22-70 \mathrm{~d}$ & $52.1^{\mathrm{a}}$ & $58.8^{\mathrm{b}}$ & $51.7^{\mathrm{a}}$ & $56.2^{\mathrm{ab}}$ & 3.4 \\
\hline \multicolumn{6}{|c|}{ Insulin, $\mu \mathrm{IU} / \mathrm{ml}$} \\
\hline $1-7 \mathrm{~d}$ & $8.9^{\mathrm{a}}$ & $12.2^{\mathrm{b}}$ & $9.2^{\mathrm{a}}$ & $10.1^{\mathrm{ab}}$ & 1.5 \\
\hline $8-21 \mathrm{~d}$ & $10.6^{\mathrm{a}}$ & $16.8^{\mathrm{b}}$ & $11.9^{\mathrm{a}}$ & $15.7^{\mathrm{ab}}$ & 2.7 \\
\hline $22-70 \mathrm{~d}$ & 23.7 & 24.7 & 22.9 & 25.0 & 1.1 \\
\hline \multicolumn{6}{|c|}{ BHBA, $\mu \mathrm{M} / \mathrm{L}$} \\
\hline $1-7 \mathrm{~d}$ & 0.68 & 0.62 & 0.64 & 0.74 & 0.05 \\
\hline $8-21 \mathrm{~d}$ & 0.88 & 0.75 & 0.81 & 0.78 & 0.06 \\
\hline $22-70 \mathrm{~d}$ & $0.91^{\mathrm{a}}$ & $0.79^{b}$ & $0.9^{\mathrm{a}}$ & $0.88^{\mathrm{ab}}$ & 0.06 \\
\hline \multicolumn{6}{|c|}{ NEFA, $\mu \mathrm{M} / \mathrm{L}$} \\
\hline $1-7 \mathrm{~d}$ & 598 & 488 & 522 & 504 & 48 \\
\hline $8-22 \mathrm{~d}$ & $624^{\mathrm{c}}$ & $570^{\mathrm{d}}$ & $616^{\mathrm{c}}$ & $562^{\mathrm{d}}$ & 32 \\
\hline $22-70 \mathrm{~d}$ & $658^{\mathrm{a}}$ & $525^{\mathrm{b}}$ & $637^{\mathrm{a}}$ & $589^{\mathrm{ab}}$ & 39 \\
\hline
\end{tabular}

${ }^{\mathrm{a}, \mathrm{b}}$ Means in the same row with different superscripts differ $(P<0.05)$.

${ }^{\mathrm{c}, \mathrm{d}}$ Means in the same row with different superscripts differ $(P<0.10)$. 
cal diseases, i.e., the supply of aminogenic and glucogenic substrates may be less optimal relative to lipogenic or ketogenic substrates. The onset of these events is highly dependent on the sustenance of DMI. In the present study, postpartum DMI was increased with the use of this DFM pre- and/or postpartum, which suggests that either control cows had depressed intake, or the DFM had a stimulatory effect, or both. The ruminal $\mathrm{pH}$ information would support that the DFM used in this study had a modulating effect. However, it is not possible to determine the specific bouts of $\mathrm{pH}$ depression that may have occurred.

In a series of studies, Nocek et al. (2000, 2002a) showed an increase in mean daily low ruminal $\mathrm{pH}$, mean nadir $\mathrm{pH}$, and $\mathrm{DM}$ digestibility of specific forages and highmoisture corn with no effect on DMI when cows were supplemented with similar microbial products. These data suggest a ruminal environment conducive to increased microbial digestion efficiency, with the potential for a greater level of aminogenic and glucogenic fuel provision. Oetzel (2000) characterized subclinical ruminal acidosis as periods of moderately depressed $\mathrm{pH}$, in which lactic acid does not consistently accumulate but elevated VFA may be contributing to the $\mathrm{pH}$ reduction. The most consistent clinical sign of subclinical acidosis is reduced and/or undulating DMI. In this study, supplementing with DFM both pre- and postpartum increased DMI and raised ruminal $\mathrm{pH}$ compared to other treatments, thereby reducing subclinical acidosis.

A balance between microorganisms that produce and utilize lactic acid is critical in maintaining a stable ruminal environment. Owens et al. (1998) suggested that adding lactic acid to the diet or supplementing feed ingredients high in lactic acid could improve the ability of the rumen to adapt to rapid increases in lactic acid production. Dawson (1995) suggested that the use of specific strains of yeast, under certain conditions, may stimulate ruminal lactic acid utilization. One probable mode of action of the DFM used in the present study was to provide a constant tonic level of lactic acid production in the rumen by use of specific bacterial strains selected to function in this manner. These microorganisms would continue to stimulate the growth and activity of lactic acid utilizing bacteria. This balance will result in sustained low or nondetectable concentrations of lactic acid in the rumen, which would tend to increase $\mathrm{pH}$. Although VFA and lactic acid were not measured in this study, ruminal $\mathrm{pH}$ reflects the dynamics of ruminal acid production, utilization, and absorption. Therefore, the control of ruminal $\mathrm{pH}$ shown in Nocek et al. (2002a) lends merit to this mode of action. The composition and dose of the DFM product is critical, however. If too much DFM is supplemented, the level of ruminal acid production can exceed the rumen's ability to consume acid (Nocek et al., 2002a)

\section{CONCLUSIONS}

Feeding a DFM product containing two specific strains of Enterococcus faecium and yeast beginning $21 \mathrm{~d}$ prepartum through d 70 of lactation increased DMI, milk production, and milk-protein percentage throughout the first $21 \mathrm{~d}$ of lactation. It also tended to do the same through 70 d compared with no DFM supplementation or prepartum supplementation only. In addition, there were improved metabolic profiles in cows as reflected by glucose, insulin, NEFA, and BHBA status. There were no effects of DFM fed only prepartum on production performance. The performance of cows supplemented with DFM beginning at parturition through $70 \mathrm{~d}$ DIM was intermediate between cows that were offered DFM both pre- and postpartum and no DFM.

\section{REFERENCES}

AOAC. 1990. Association of Official Analytical Chemists. Official Methods of Analysis 15th ed. AOAC Arlington, VA.

Dawson, K. A. 1995. The use of yeast strain 8417 in manipulating ruminant high concentrate diets. Pages 25-36 in Proc 56th Minnesota Nutrition Conference, St. Paul, MN.

Drackley, J. K. 1999. Biology of dairy cows during the transition period: the final frontier? J. Dairy Sci. 82:2259-2273.

Garrett, E. F., K. V. Nordland, W. J. Goodger, and G. R. Oetzel. 1997. A cross-sectional field study investigating the effect of periparturient management on ruminal $\mathrm{pH}$ in early lactation dairy cows. J. Dairy Sci. 80(Suppl. 1):169. (Abstr.)

Gibbard, S., and P. J. Watkins. 1968. Amicro-method for energymatic determination of D-B-hydroxy butyrate and acetoacetate. Clin. Chim. Acta 19:511-521.

Kramer, C. Y. 1956. Extension of multiple range test to group means with unequal numbers of replications. Biometrics. 12:309-310.

Nocek, J. E., W. P. Kautz, J. A. Z. Leedle, and J. G. Allman. 2000. Altering diurnal $\mathrm{pH}$ and in situ digestion in dairy cows with ruminal supplementation of direct-fed microbials and yeast. J. Dairy Sci. 83(Suppl. 1):296. (Abstr.)

Nocek, J. E. 1997. Bovine acidosis: Implications on laminitis. J. Dairy Sci. 80:1005-1028.

Nocek, J. E., T. Ueda, I. Shinzato, H. Sato, T. Fujieda, and H. Suzuki. 2002b. Diurnal ruminal $\mathrm{pH}$ profiles of dairy cows during transition and influence of $\mathrm{pH}$ on ruminal digestibility. Prof. Anim. Sci. 18:151-157.

Nocek, J. E., W. P. Kautz, J. A. Z. Leedle, and J. G. Allman. 2002a. Ruminal supplementation of direct-fed microbials on diurnal $\mathrm{pH}$ variation and in situ digestion in dairy cattle. J. Dairy Sci. 85:429-433.

Oetzel, G. R. 2000. Clinical aspects of ruminal acidosis in dairy cattle. Pages 46-53 in 33rd Proc. American Association of Bovine Practitioners, Rapid City, SD.

Owens, F. N., D. S. Secrist, W. J. Hill, and D. R. Gill. 1998. Acidosis in cattle. A review. J. Anim Sci. 76:275-286.

SAS JMP. 1996. Software: Statistical discovery software. Version 3.1.6.2. SAS Inst., Cary, NC.

Van Soest, P. J., J. B. Robertson, and B. A. Lewis. 1991. Methods for dietary fiber, neutral detergent fiber and nonstarch polysaccharides in relation to animal nutrition. J. Dairy Sci. 74:3583-3597. 